\title{
GAGE5 Gene
}

National Cancer Institute

\section{Source}

National Cancer Institute. GAGE5 Gene. NCI Thesaurus. Code C104480.

This gene may play a role in tumor antigenicity. 